\title{
Occult hepatitis B virus infection in Egyptian hemodialysis patients with or without hepatitis $C$ virus infection
}

This article was published in the following Dove Press journal:

Pathology and Laboratory Medicine International

10 August 2010

Number of times this article has been viewed

\author{
Hisham Ismail'* \\ Mohamed Soliman ${ }^{2}$ \\ Nahed Ismail ${ }^{3}$ \\ 'Department of Molecular Diagnosis, \\ GEBR Institute, ${ }^{2}$ Department of \\ Clinical Pathology, College of \\ Medicine, Menoufia University, \\ Menoufia, Egypt; ${ }^{3}$ Department of \\ Pathology and Department of \\ Microbiology and Immunology, \\ Meharry Medical College, Nashville, \\ Tennessee, USA \\ *Current affiliation: College of \\ Medicine, Qassim University, Saudi \\ Arabia
}

\begin{abstract}
Hepatitis B virus (HBV) and hepatitis $\mathrm{C}$ virus (HCV) infections are frequent in patients with end-stage renal disease who are on maintenance hemodialysis. There are limited data about the prevalence of occult HBV infection in patients on long-term hemodialysis. Occult HBV is defined as positive HBV DNA in the blood in the absence of hepatitis B surface antigen in the serum. In this study, we determined the prevalence of occult HBV in hemodialysis patients with or without HCV infection. The study included 116 patients with end-stage renal disease on chronic hemodialysis, of whom 64 patients were HCV RNA positive (Group 1), and 52 were HCV RNA negative (Group 2). We found that four of 64 (6.3\%) hemodialysis patients with HCV infection (Group 1) had occult HBV, while only two of 52 (3.8\%) hemodialysis patients without HCV (Group 2) had occult HBV. We then examined whether gender-matched hemodialysis patients with positive HBV DNA in the two hemodialysis groups differed in specific parameters, ie, age, degree of liver dysfunction, and presence of coinfection with schistosomiasis, a common parasitic infection of the liver. We found no significant difference between the groups having positive HBV DNA with regard to serum levels of liver enzymes, aspartate transaminase, albumin, and hepatitis B core antigen $(P>0.05)$. However, we detected significantly higher levels of alanine transaminase, a prolonged duration of hemodialysis, and higher levels of schistosomal antibodies in Group 1 than in Group 2. Interestingly, we found that the presence of schistosomal antibodies, history of past blood transfusion, and longer hemodialysis duration could distinguish patients with occult HBV infection from those with HBV DNA negative infection in hemodialysis patients. In conclusion, the prevalence of occult HBV in chronic hemodialysis patients is low, and does not significantly differ between hemodialysis patients with or without HCV coinfection.
\end{abstract}

Keywords: occult hepatitis B virus, hepatitis C virus, schistosomiasis, hemodialysis

\section{Introduction}

Hepatitis B virus (HBV) infection is a major global health problem. HBV infection can have different clinical presentations that range from a carrier state to cirrhosis and hepatocellular carcinoma. ${ }^{1} \mathrm{HBV}$ and $\mathrm{HCV}$ are common nosocomial infections that cause higher rates of mortality and morbidity in maintenance hemodialysis patients than in the general population. Chronic HBV infection is usually diagnosed when circulating hepatitis B surface antigen is detected in serum in the presence of antibodies to hepatitis B surface antigen and/or hepatitis B core antibodies. However, the availability of highly sensitive polymerase chain reaction (PCR)-based techniques has allowed the identification of HBV DNA in hepatitis B surface antigen-negative individuals, with or without circulating antibodies to hepatitis B surface antigen and/or hepatitis B core antigen. ${ }^{2}$ Recently, a group of patients has been identified as having occult HBV infection defined by positive HBV DNA in the liver or blood, while hepatitis B surface antigen is undetectable in serum as measured
Correspondence: Nahed Ismai Department of Pathology and Department of Microbiology and Immunology, Meharry Medical College, 1005 Dr D. B. Todd Blvd,

Nashville,TN, USA

Tel +I 6153276364

Fax + I 6I5 3276409

Email nismail@mmc.edu
(C) 2010 Ismail et al, publisher and licensee Dove Medical Press Ltd. This is an Open Access article which permits unrestricted noncommercial use, provided the original work is properly cited. 
by current commercial hepatitis B surface antigen assays. ${ }^{3}$ Although the exact cause of occult HBV is not completely understood, several studies have indicated that occult HBV infection status can be associated with mutant viruses that are usually undetectable by current hepatitis B surface antigen assays. Other studies have suggested that occult HBV can be due to suppression of viral replication, gene expression, and virus secretion. ${ }^{4}$ When occult HBV occurs after recovery from acute HBV infection, it is usually associated with detectable hepatitis B surface antibodies or hepatitis B core antibodies. In other patients, occult HBV may exist in the absence of all anti-HBV antibody markers. ${ }^{5}$ Several studies have reported higher prevalence of occult $\mathrm{HBV}$ infection in patients with chronic HCV, hepatocellular carcinoma, cryptogenic liver disease, intravenous drug use, human immunodeficiency virus (HIV) infection, and in hemophilic patients who have received several blood transfusions and in blood donors ${ }^{6-12}$ when compared with the general population. In addition to the potential risk of nosocomial HBV transmission in hemodialysis units, occult HBV infection increases the risk of HBV transmission through blood transfusion and organ transplantation. ${ }^{9}$ Despite the potential clinical importance of occult HBV infection, the existing data are limited for the prevalence of occult $\mathrm{HBV}$ among Egyptian patients on long-term hemodialysis. ${ }^{10,12}$ Furthermore, screening for occult HBV in dialysis patients in Egypt by biochemical testing is problematic and insensitive due to the fact that aminotransferase activity and serum level is usually decreased in these patients. ${ }^{11}$

This study was designed to investigate the prevalence of occult HBV infection in hemodialysis patients using a highly sensitive and specific PCR method to compare the prevalence of occult HBV infection among HCV-positive and HCVnegative hemodialysis patients, and to correlate the clinical, epidemiologic, and laboratory characteristics of patients with occult HBV in the presence or absence of HCV coinfection. These characteristics include duration of dialysis, serum alanine transaminase (ALT) and aspartate transaminase (AST), markers of HBV infection such as hepatitis B surface antigen, hepatitis B surface antibodies, and hepatitis B core antibodies, or HCV infection, such as anti-HCV antibodies and HCV RNA, as well as the presence of schistosoma coinfection as detected by the presence of anti-schistosoma antibodies in serum.

\section{Subjects and methods Human subjects}

A total of 116 patients with end-stage renal disease on regular hemodialysis were included in this study. Patients were selected from the Hemodialysis Unit, Internal Medicine Department,
Main University Hospital, Faculty of Medicine, Menoufiya University. Informed consent was obtained from all patients involved in the study. Patients were divided according to HCV PCR status into two groups, ie, 64 patients who were HCV RNA-positive (Group 1) and 52 patients who were HCV RNAnegative (Group 2). Chronic HCV infection was defined by the presence of anti-HCV antibodies for more than six months and positive serum HCV RNA. ${ }^{13}$ Demographic and laboratory information on all subjects was obtained.

Inclusion criteria included end-stage renal disease on regular hemodialysis (for at least 6 months' duration), with or without HCV RNA positivity by PCR. Exclusion criteria included acute or chronic HBV infection as marked by positive hepatitis B surface antigen, other causes of liver dysfunction (eg, primary biliary cirrhosis, autoimmune hepatitis, continued alcohol abuse, autoimmune hepatitis, and HIV infection) and being on treatment with interferon and/or ribavirin. A complete medical history, including HBV vaccination history, duration of hemodialysis, etiology of end-stage renal disease, past blood transfusion, history of schistosomiasis, and complete physical examination, was obtained for all patients. Blood samples were collected from all patients before initiation of hemodialysis. Blood was centrifuged to separate serum or plasma. Samples were stored at $-80^{\circ} \mathrm{C}$ until processed.

\section{Laboratory tests}

Liver enzymes and serum albumin were analyzed by a chemistry autoanalyzer (Synchron CX5, Beckman Instrument Inc., Scientific Instrument Division, Fullerton, CA). Schistosoma (ie, bilharzial) antibodies were assessed using an indirect hemagglutination assay with adult Schistosoma mansoni worm antigens (Fumouze Laboratories, Levallois-Perret, France ${ }^{14}$ ). Hepatitis B core antibodies and hepatitis B surface antigen as markers of previous/resolved or chronic HBV infection were detected by electrochemiluminescence immunoassay on Roche Elecsys 201014. For specimens that were hepatitis B surface antigen-negative by one assay, the results were confirmed by testing on other commercial hepatitis B surface antigen assays (Modular Analytics E170 and Elecsys module immunoassay analyzer). The sensitivities of the five hepatitis B surface antigen assays ranged from 0.03 to $0.2 \mathrm{IU} / \mathrm{mL}$. All procedures were performed according to the manufacturers' instructions.

\section{Detection of HBV DNA by polymerase chain reaction}

Samples from each patient were tested for HBV DNA using nested PCR (core fragment) techniques, as described previously. ${ }^{15}$ Briefly, DNA was extracted from patients' sera 
using the Invisorb nucleic acid extraction kit (Invitek, Germany). HBV DNA was amplified using a thermocycler (Perkin Elmer 9700). HBV DNA was amplified using two different primer pairs (First set: F 5'-GTCTGCGGCGTTTTATC-3'; and R 5'-ACAGTGGGGGAAAGC-3'; second set: F 5'-TGCCCGTTTGTCCTCTA-3' and R 5'AGAAACGGRCTGAGGC-3'. Samples from all positive cases were retested to confirm positive results. The first round of PCR was performed with an outer primer set for 35 cycles $\left(94^{\circ} \mathrm{C}\right.$ for $40 \mathrm{sec}, 55^{\circ} \mathrm{C}$ for $40 \mathrm{sec}$, and $72^{\circ} \mathrm{C}$ for $\left.40 \mathrm{sec}\right)$. The second round was performed with an inner primer set for 25 cycles $\left(94^{\circ} \mathrm{C}\right.$ for $40 \mathrm{sec}, 57^{\circ} \mathrm{C}$ for $40 \mathrm{sec}$, and $72^{\circ} \mathrm{C}$ for $40 \mathrm{sec}$ ), followed by the extension reaction. Nested PCR products were subjected to electrophoresis on a 3\% agarose gel stained with ethidium bromide, and DNA was observed under ultraviolet light. ${ }^{15}$

\section{HBV DNA quantification by real-time polymerase chain reaction}

Samples that were positive by nested PCR were further tested by highly sensitive and specific real-time PCR. HBV DNA was extracted from $850 \mu \mathrm{L}$ of plasma by the Cobas AmpliPrep instrument according to the manufacturer's instructions. The Cobas TaqMan 48 analyzer was used for automated real-time PCR amplification and detection of PCR products according to the manufacturer's instructions. HBV DNA levels were expressed in IU/mL. The HBV detection limit was $12 \mathrm{IU} / \mathrm{mL}$ and the $\mathrm{HCV}$ limit was $15 \mathrm{IU} / \mathrm{mL}$.

\section{Statistical analysis}

Data were analyzed using Sigma Plot software (SPSS, version 2). $P$ values were determined using the Chi-square test $\left(\chi^{2}\right)$ to study the association between two qualitative variables (compare between proportions); and Student's two-tailed $t$-test for comparisons between two groups having quantitative variables (ie, compare sample means). Data are presented as percentages, means, and standard deviation (SD). $P$ values less than 0.01 were considered highly significant, and those less than 0.05 were considered significant.

\section{Results}

We first examined whether patients with or without HCV differ in factors known to be associated with nosocomial transmission and/or higher prevalence of $\mathrm{HBV}$ and $\mathrm{HCV}$ infections in hemodialysis patients. As summarized in Table 1, the mean age of the patients in groups 1 and 2 was $47.57 \pm 14.88$ and $42.54 \pm 15.68$ years, respectively. Males constituted 53.1\% $(\mathrm{n}=34)$, and $61.5 \%(\mathrm{n}=32)$ in groups 1 and 2, respectively. Mean hemodialysis periods for groups 1 and 2 were $5.28 \pm 3.20$ and $2.62 \pm 1.61$ years (range, 1.5-11, and 0.0-6.5 years), respectively. A history of past blood transfusion in groups 1 and 2 was obtained from $38(59.4 \%)$ and $40(76.9 \%)$ patients, respectively. None of our hemodialysis patients had received hepatitis $B$ vaccination in the past.

We then examined the prevalence of occult hepatitis B virus infections in the two groups of hemodialysis patients as measured by positive HBV DNA in the presence or absence of anti-hepatitis B core antigen. As shown in Table 1, we found that $4 / 64(6.3 \%)$ hemodialysis patients who were infected with HCV (Group 1) had occult HBV, while only $2 / 52$ (3.8\%) hemodialysis patients without HCV infection (Group 2) had occult HBV. We confirmed positive HBV DNA with real-time PCR. All patients with positive HBV DNA had undetectable hepatitis B surface antigen in their sera, suggesting that these patients had occult HBV infection.

Comparing the two hemodialysis patient groups, we did not detect significant differences in age, gender, history of blood transfusion, serum AST, serum albumin, positive antihepatitis B core antigen, or positive HBV DNA $(P>0.05)$. However, serum ALT and mean hemodialysis duration were significantly higher in Group 1 than in Group $2(P=0.013$, and $P=0.0003$, respectively). Interestingly, significantly a higher level of schistosomal antibodies was detected in Group 1 than in Group $2(P=0.03)$, suggesting a concurrent or recent coinfection with schistosomiasis, a common liver disease affecting Egyptian patients.

We next examined the presence or absence of hepatitis $B$ core antibodies as a marker of previous HBV infection in the two groups of patients, as well as possible correlation with certain parameters, including age, gender, liver enzymes, serum albumin, and coinfection with Schistosoma. A total of $20(17.2 \%)$ patients had positive hepatitis B core antibodies, with (14 [21.9\%] patients in Group 1 and 6 [11.5\%] patients in Group 2, Table 1). There was no significant correlation between the presence of hepatitis B core antibodies and gender, serum AST and ALT, serum albumin, or positive HBV DNA in either group of patients. The presence of hepatitis B core antibodies, in the absence of HBV DNA suggests recovery from a recent/acute HBV infection in those patients. However, there was a significant relationship between hepatitis B core antibodies and higher hemodialysis duration, and history of blood transfusion and presence of schistosomal antibodies in both groups (Table 2). 
Table I Clinical and laboratory characteristics of hepatitis C virus RNA positive (Group I) and hepatitis C virus RNA negative (Group 2) hemodialysis patients

\begin{tabular}{|c|c|c|c|c|}
\hline Characteristics & $\begin{array}{l}\text { All patients } \\
(n=116)\end{array}$ & $\begin{array}{l}\text { Group I } \\
(n=64)\end{array}$ & $\begin{array}{l}\text { Group } 2 \\
(n=52)\end{array}$ & $P$ value \\
\hline Age (years, range) & $20-72$ & $20-72$ & $22-64$ & \\
\hline Age (years, mean $\pm S D$ ) & $45.41 \pm 15.33$ & $47.75 \pm 14.88$ & $42.54 \pm 15.68$ & 0.19 \\
\hline Males (\%) & $66(56.9)$ & $34(53.1)$ & $32(61.5)$ & 0.59 \\
\hline Females (\%) & $50(43.1)$ & $30(46.9)$ & $20(38.5)$ & \\
\hline Duration of hemodialysis (years, mean $\pm S D$ ) & $4.09 \pm 2.92$ & $5.28 \pm 3.20$ & $2.62 \pm 1.61$ & $0.0003 * *$ \\
\hline Duration of hemodialysis (years, range) & $6.5-11$ & $|.5-| \mid$ & $0.5-6.0$ & \\
\hline Positive history of transfusion (\%) & $78 / 116(67.2)$ & $38 / 64(59.4)$ & $40 / 52(76.9)$ & 0.175 \\
\hline Positive schistosoma antibodies & $74 / 116(63.8)$ & $50 / 64(78.1)$ & $24 / 52(46.2)$ & $0.03 *$ \\
\hline AST (IU/L) & $28.73 \pm 5.46$ & $29.81 \pm 7.28$ & $27.65 \pm 3.65$ & 0.174 \\
\hline ALT (IU/L) & $30.08 \pm 5.13$ & $32.03 \pm 7.28$ & $28.12 \pm 2.97$ & $0.013^{*}$ \\
\hline Albumin (g/dL) & $3.73 \pm 0.36$ & $3.84 \pm 0.32$ & $3.62 \pm 0.39$ & $0.022 *$ \\
\hline Positve anti-HBc (\%) & $20 / 116(17.2)$ & $14 / 64$ (2I.9) & 6/52 (I I.5) & 0.48 \\
\hline Positive HBV DNA (\%) & $6 / 116(5.2)$ & $4 / 64(6.3)$ & $2 / 52(3.8)$ & 1.0 \\
\hline
\end{tabular}

*significant $(P<0.05)$; **highly significant $(P<0.01)$.

Abbreviations: AST, aspartate transaminase; ALT, alanine transaminase; anti-HBc, hepatitis B core antibody; HBV DNA, hepatitis B virus DNA by polymerase chain reaction; SD, standard deviation.

Finally, as shown in Table 3, we investigated whether there was a significant correlation between the presence and absence of occult HBV in all hemodialysis patients (ie, groups 1 and 2) and certain parameters or risk factors, such as age, gender, longer hemodialysis duration, history of blood transfusion, presence of schistosomal antibodies, serum AST and ALT, and serum albumin. Our data indicate that there was a significant positive correlation between the presence of HBV DNA and age $\geq 40$ years, prolonged hemodialysis duration, positive history of blood transfusion, presence of significantly high levels of schistosomal antibodies, and high serum levels of AST and ALT $(P<0.05)$. However, there was no significant relationship between HBV DNA positivity and gender or serum level of albumin $(P>0.05$, Table 3$)$.

\section{Discussion}

In our study, we found that occult HBV was detected in 6 $(5.2 \%)$ of 116 patients on chronic hemodialysis therapy

Table 2 Relationship between hepatitis B core antibody and clinical and laboratory parameters in hemodialysis patients with positive (Group I) or negative (Group 2) hepatitis C virus infection

\begin{tabular}{|c|c|c|c|c|c|c|c|}
\hline \multirow{2}{*}{$\begin{array}{l}\text { Clinical/laboratory } \\
\text { parameters }\end{array}$} & \multicolumn{3}{|c|}{ Group I $(n=64)$} & \multicolumn{3}{|c|}{ Group $2(n=52)$} & \multirow[t]{2}{*}{$P_{\text {value }}^{\dagger}$} \\
\hline & $\begin{array}{l}\text { Anti-HBc } \\
\text { positive } \\
(n=14) \\
n(\%)\end{array}$ & $\begin{array}{l}\text { Anti-HBc } \\
\text { negative } \\
(n=50) \\
n(\%)\end{array}$ & $P$ value & $\begin{array}{l}\text { Anti-HBc } \\
\text { positive } \\
(n=6) \\
n(\%)\end{array}$ & $\begin{array}{l}\text { Anti-HBc } \\
\text { negative } \\
(n=46) \\
n(\%)\end{array}$ & $P$ value & \\
\hline Age (years) $\leq 40$ & $6(42.9)$ & $16(32)$ & 0.66 & $2(33.3)$ & $22(47.8)$ & 0.65 & \\
\hline$>40$ & $8(57.1)$ & $34(68)$ & 0.66 & $4(66.7)$ & $24(52.2)$ & 0.73 & \\
\hline Males (\%) & $4(28.6)$ & $26(52)$ & 0.40 & $2(33.3)$ & $18(39.1)$ & 1.0 & 0.65 \\
\hline Females (\%) & $10(71.4)$ & $24(48)$ & 0.88 & $4(66.7)$ & $28(60.9)$ & 0.74 & \\
\hline \multicolumn{8}{|l|}{ Duration of hemodialysis } \\
\hline $0.5-6$ years & $4(28.6)$ & $44(88)$ & $0.008 * *$ & $0(0 \%)$ & $30(65.2)$ & $0.06 *$ & $0.0001 * *$ \\
\hline $6-11$ years & $10(7 \mid .4)$ & $6(12)$ & $0.005^{* *}$ & $6(100)$ & $16(34.8)$ & $0.03^{*}$ & $0.000 I^{* *}$ \\
\hline $\begin{array}{l}\text { Positive history of blood } \\
\text { transfusion }\end{array}$ & $10(71.4)$ & $16(32)$ & 0.06 & $2(33.3)$ & $10(21.7)$ & 0.65 & $0.000 I^{* *}$ \\
\hline Positive for schistosomiasis & $12(85.7)$ & $38(76)$ & 0.58 & $4(66.7)$ & $20(43.5)$ & 0.45 & $0.002^{* *}$ \\
\hline AST (IU/L) (mean \pm SD) & $31.1 \pm 4.7$ & $29.4 \pm 7.8$ & 0.48 & $28.0 \pm 2.0$ & $27 \pm 3.8$ & 0.79 & 0.32 \\
\hline ALT (IU/L) (mean $\pm S D)$ & $32.5 \pm 4.7$ & $31.8 \pm 7.9$ & 0.22 & $28.3 \pm 1.0$ & $28.0 \pm 3.0$ & 0.80 & 0.18 \\
\hline Albumin $(g / d L)($ mean $\pm S D)$ & $3.6 \pm 0.1$ & $3.8 \pm 0.3$ & 0.94 & $3.5 \pm 0.5$ & 3.6 & 0.78 & 0.87 \\
\hline Positive HBV DNA & $4(28.6)$ & $0(0)$ & 0.17 & $2(33.3)$ & $0(0)$ & 0.19 & 0.64 \\
\hline
\end{tabular}

${ }^{\dagger} P$ value comparing positive cases of HBV between Group I and Group 2; *significant $(P<0.05)$; **highly significant $(P<0.0 \mathrm{I})$.

Abbreviations: AST, aspartate transaminase; ALT, alanine transaminase; HBV DNA, hepatitis B virus DNA by polymerase chain reaction; anti-HBc, hepatitis B core antibody; SD, standard deviation. 
Table 3 Relationship between hepatitis B virus DNA (occult HBV) and parameters for the hemodialysis patients entered into this study

\begin{tabular}{|c|c|c|c|}
\hline Parameters & $\begin{array}{l}\text { Occult HBV DNA } \\
\text { positive }(n=6), n(\%)\end{array}$ & $\begin{array}{l}\text { Occult HBV DNA } \\
\text { negative }(n=1 \mid 0), n(\%)\end{array}$ & t $P$ value \\
\hline Age (years) $\leq 40$ & $0(0)$ & $46(4 \mid .8)$ & $0.0001 * *$ \\
\hline$>40$ & $6(100)$ & $64(58.2)$ & $0.000 I^{* *}$ \\
\hline Males (\%) & $2(33.3)$ & $48(43.6)$ & 0.15 \\
\hline Females (\%) & $4(66.7)$ & $62(56.4)$ & 0.15 \\
\hline \multicolumn{4}{|l|}{ Duration of hemodialysis } \\
\hline $0.5-6$ years & $2(33.3)$ & $98(89)$ & $0.0001 * *$ \\
\hline$>6-11$ years & $4(66.7)$ & $12(11)$ & $0.0001 * *$ \\
\hline Positive history of blood transfusion & $6(100)$ & $32(29.1)$ & $0.0001 * *$ \\
\hline Positive schistosomiasis & $6(100)$ & $68(61.8)$ & $0.0001 * *$ \\
\hline AST (IU/L, mean $\pm S D)$ & $32.3 \pm 4.5$ & $28.6 \pm 6.0$ & $0.000 I^{* *}$ \\
\hline $\mathrm{ALT}(\mathrm{IU} / \mathrm{L}$, mean $\pm \mathrm{SD})$ & $34.0 \pm 4.5$ & $30 \pm 6.0$ & $0.000 I^{* *}$ \\
\hline Albumin $(\mathrm{g} / \mathrm{dL}$, mean $\pm \mathrm{SD})$ & $3.5 \pm 0.1$ & $3.7 \pm 0.3$ & 0.258 \\
\hline
\end{tabular}

tP value comparing positive cases of HBV between Group I and Group 2; *significant $(P<0.05)$; **highly significant $(P<0.0 \mathrm{I})$.

Abbreviations: AST, aspartate transaminase; ALT, alanine transaminase; HBV DNA, hepatitis $B$ virus DNA by polymerase chain reaction; SD, standard deviation.

(4 [6.3\%] patients in Group 1, and $2[3.8 \%]$ patients in Group 2]). Also, we found that 20 (17.2\%) patients had hepatitis B core antibody seropositivity (14 [21.9\%] patients in Group 1 and 6 [11.5\%] patients in Group 2). Our study is important because it examined the proportion of HCV RNA-positive patients among the population studied and the incidence of occult HBV in the presence or absence of $\mathrm{HCV}$ coinfection, which has not been examined in detail elsewhere. Although the incidence of occult HBV in our hemodialysis patient population is not high compared with that in the general population, it is considerably high compared with other studies. In a study by Minuk et $\mathrm{al}^{16}$ including 239 hemodialysis patients who were hepatitis B surface antigen-negative, $9(3.8 \%)$ patients were HBV DNA-positive by real-time PCR. In another study by Yakaryilmaz et $\mathrm{al}^{17}$ of 188 patients with end-stage renal disease on maintenance hemodialysis (mean duration $98 \pm 66$ months), occult HBV was identified in only five $(2.7 \%)$ patients. In other studies, occult HBV was not detected. ${ }^{8,18}$ On the other hand, other studies have revealed a higher prevalence of occult HBV in hemodialysis patients. For example, a study by Siagris et $\mathrm{al}^{10}$ reported that HBV DNA was detected by PCR in 10/49 (20.4\%) hemodialysis patients and in $3 / 48(6.3 \%)$ patients with normal renal function $(P=0.041)$. HBV DNA concentrations were low $(<103$ copies $/ \mathrm{mL})$ in both groups. HBV DNA-positive hemodialysis patients had a significantly lower prevalence of past $\mathrm{HBV}$ vaccination and lower hepatitis B surface antibody titers in serum than HBV DNA-negative patients of the same group. Similarly, Besisik et al ${ }^{19}$ who studied 33 hemodialysis patients (mean age $36 \pm 9$ years) with HCV infection, reported that positive HBV DNA and negative hepatitis B surface antigen (ie, occult HBV) was detected in $12 / 33(36.4 \%)$ patients. However, in this study, only $3 / 33$ (9.1\%) hemodialysis patients had had HBV vaccination, which is much lower than that reported by Siagris et al. ${ }^{10}$ Taken altogether, the fact that higher prevalence of occult $\mathrm{HBV}$ is detected in hemodialysis patients with no history of $\mathrm{HBV}$ vaccination suggests that the lack of past $\mathrm{HBV}$ vaccination could be a risk factor that could account, in part, for the higher prevalence of occult HBV infection in hemodialysis patients.

The discrepancy in the reported incidence of occult HBV (0.0\%-36.4\%) between several studies, including our study, could be due to several factors. One could be the differences in sensitivity of the methods used for detection of the virus genome (nested PCR versus quantitative real-time PCR). ${ }^{5}$ Occult $\mathrm{HBV}$ is thought to be due to infection with mutant virus that cannot be detected with commercially available molecular methods. ${ }^{20}$ Such mutations could result in impaired antigen production by the virus, a diminished rate of replication, or could facilitate viral persistence. ${ }^{21}$ Our future studies will examine HBV genotypes to determine whether HBV mutations account for the presence of occult HBV in our hemodialysis population. Another reason could be quantitative differences in the levels of HBV viremia during the course of the disease in different patient populations. This conclusion is based on data by Lili et $\mathrm{al}^{22}$ who examined repeated sera from the same patients for the presence of HBV DNA, and demonstrated inconsistent results with previously negative samples being positive for HBV DNA and vice versa, which suggests a fluctuating level of viremia in the course of the disease. ${ }^{23}$ There are also differences in 
the prevalence of $\mathrm{HBV}$ in the general population according to geographic location, which can influence the prevalence of HBV infection among hemodialysis patients. ${ }^{26}$ Furthermore, differences in the mode of transmission of infection (ie, blood transfusion, intravenous drug abuse, multiple sexual partners) can influence the amount of virus transmitted, and thus the viremia level. This conclusion is based on studies showing that occult HBV infections were detected in $10 \%, 0 \%-15 \%$, and $45 \%$ of patients with HIV infection, ${ }^{25}$ blood donors, ${ }^{6}$ and intravenous drug users, respectively. ${ }^{7}$ Also, variation in the degree of chronic alcohol consumption could downregulate HBV antigen expression, and thus account, in part, for the high rate of HBV DNA-positive tests in the absence of hepatitis B surface antigen. ${ }^{26}$ Alternatively, occult HBV in chronic alcoholism could be due to low circulating levels of viral particles, rendering hepatitis B surface antigen undetectable with commercial kits, whereas HBV DNA remains positive using the highly sensitive PCR technique. ${ }^{21}$ In our study, patients who abused alcohol were excluded, which may partially account for the low incidence of occult HBV in our study. Lastly, the type of sample can influence the detection of occult HBV, as suggested by Oesterreicher et $\mathrm{al}^{27}$ who reported positive HBV DNA in the absence of hepatitis B surface antigen (ie, occult HBV) in peripheral blood mononuclear cells, but not in serum, from 6 of 67 hemodialysis patients $(8.9 \%)$ with no clinical and biochemical signs of liver disease.

Our study demonstrated that hepatitis B core antibody levels were not significantly higher in patients in Group 1 (21.9\%) than those in Group 2 (11.5\%). Serologic detection of hepatitis B core antibodies is common in hepatitis B surface antigen-negative patients with chronic hepatitis C. ${ }^{23}$ In agreement with our results, studies by Helmy et $\mathrm{a}^{28}$ and Jilg et $\mathrm{al}^{29}$ found a high correlation between anti-HCV and hepatitis B core antibodies. Because HBV and HCV have similar transmission models, coinfection of both viruses is expected to be prevalent.

Regarding schistosomiasis, our data show a significant difference between the presence of occult HBV or hepatitis B core antibodies in patients with and without HCV infection and schistosomal infection. Hemodialysis patients with HCV infection have more schistosomiasis coinfection than hemodialysis patients without HCV (78.1\% versus $46.2 \%$, respectively, Tables 1 and 2). Schistosomiasis is endemic in Egypt. ${ }^{30}$ Our study is consistent with other studies suggesting that schistosomiasis is a major risk factor for
HCV (but not HBV) infection ${ }^{31}$ and end-stage renal disease in Egypt. ${ }^{31}$ The high frequency of coinfection may be the result of $\mathrm{HCV}$ transmission during parenteral schistosomal therapy or schistosomiasis-related surgery, but it also seems possible that certain individuals are particularly susceptible to both schistosomal and HCV infection. It is possible that immune suppression associated with hemodialysis, as well as hepatic coinfection with $\mathrm{HCV}$, may suppress effective immune responses against Schistosoma, and thus lead to chronic schistosomiasis and vice versa. This conclusion is based on the findings that HCV infection stimulates Type 1 immune responses, which causes immune deviation and inhibition of protective Type 2 responses against Schistosoma eggs. ${ }^{33}$ Indeed, a recent study suggested that Th1/ Th2 cytokine imbalance is involved in the pathogenesis of chronic HCV infection and that Schistosoma mansoni coinfection induces more alteration in the cytokine milieu, along with more severe liver disease. ${ }^{33}$

Despite none of our studied patients having evidence of prior HBV vaccination, the prevalence of occult HBV was low. However, it is possible that patients undergoing chronic hemodialysis therapy may have either a lower response rate to hepatitis B vaccination compared with healthy subjects, or have transient responses to vaccination as a result of profound immune suppression. ${ }^{34,35}$

Age, duration of dialysis, and biochemical parameters were not significantly different in our patients with and without occult HBV infection. Our data showed no significant difference between hepatitis B core antibody levels or occult $\mathrm{HBV}$ in patients with and without $\mathrm{HCV}$ infection, and liver transaminase levels. Because serum AST and ALT levels are commonly used as screening tests for liver disease in hemodialysis patients, recognition of liver damage may be hampered by reduction in aminotransferase values in these patients. ${ }^{36}$ Aminotransferase levels in the "normal" range for the general population may be indicative of a pathologic state in the dialysis setting. Thus, an increase in the baseline levels of these enzymes does not have to reach the "high abnormal" range to indicate the presence of HBV-related liver disease, ${ }^{11}$ suggesting that the relationship between aminotransferase activity and degree of HBV-mediated liver damage in dialysis patients is not accurate. This dyscorrelation could be due to an intermittent increase in aminotransferase activity and fluctuation of HBV viral load over time, possible infection with low virulent HBV strains, and/or quality and magnitude of host immune responses against infection. Because the levels of aminotransferase activity in patients with chronic 
renal failure undergoing maintenance dialysis ${ }^{37}$ or even in the predialysis stage ${ }^{36}$ are usually depressed, it is difficult to detect liver disease by biochemical tests.

\section{Conclusion}

The overall prevalence of occult HBV in adult end-stage renal disease patients on maintenance hemodialysis is $5.2 \%$ (being $6.3 \%$ and $3.8 \%$ in those with positive and negative $\mathrm{HCV}$, respectively). All patients with longer hemodialysis periods, past blood transfusion, or hepatitis B core antibody positivity should be screened for probable occult HBV infection. Furthermore, we recommend that the results of any occult HBV study be evaluated in light of the interaction between the hepatitis B surface antigen positivity for a certain region and the frequency of $\mathrm{HBV}$ mutants in that region that can be detected by highly sensitive and specific commercially available serologic tests.

\section{Disclosure}

The authors report no conflict of interest in this work.

\section{References}

1. Kennedy M, Alexopoulos SP. Hepatitis B virus infection and liver transplantation. Curr Opin Organ Transplant. 2010;15(3): 310-315.

2. Zaghloul $\mathrm{H}$, El-Sherbiny W. Detection of occult hepatitis $\mathrm{C}$ and hepatitis $\mathrm{B}$ virus infections from peripheral blood mononuclear cells. Immunol Invest. 2010;39(3):284-291.

3. Paraskevis D, Beloukas A, Haida C, et al. Development of a new ultra sensitive real-time PCR assay (ultra sensitive RTQ-PCR) for the quantification of HBV-DNA. Virol J. 2010;12:7:57.

4. Cao GW. Clinical relevance and public health significance of hepatitis B virus genomic variations. World J Gastroenterol. 2009; 15(46):5761-5769.

5. Torbenson M, Thomas D. Occult hepatitis B. Lancet Infect Dis. 2002; 2(8):479-486.

6. Allain JP. Occult hepatitis B infection. Transfus Clin Biol. 2004;11(1): 18-25. French.

7. Torbenson M, Kannangai R, Astemborski J, et al. High prevalence of occult hepatitis B in Baltimore injection drug users. Hepatology. 2004;39(1):51-57.

8. Goral V, Ozkul H, Tekes S, et al. Prevalence of occult HBV infection in hemodialysis patients with chronic HCV. World $J$ Gastroenterol. 2006;12(21):3420-3424

9. Hu KQ. Occult hepatitis B infection and its clinical implications. JViral Hepat. 2002;9:243-257.

10. Siagris D, Christofidou M, Triga K, et al. Occult hepatitis B virus in hemodialysis patients with chronic HCV infection. J Nephrol. 2006; 19(3):327-333.

11. Fabrizi F, Lunghi G, Martin P. Hepatitis B virus infection in hemodialysis: Recent discoveries. J Nephrol. 2002;15(5):463-468.

12. Otedo AE, Mc'Ligeyo SO, Okoth FA, Kayima JK. Seroprevalence of hepatitis $\mathrm{B}$ and $\mathrm{C}$ in maintenance dialysis in a public hospital in a developing country. S Afr Med J. 2003;93(5):380-384.

13. Anwar W, Sarwar M, Hussain AB, Tariq WU, Saif M. Significance of occult HBV infection in patients with chronic hepatitis C. $J$ Coll Physicians Surg Pak. 2006;16(3):192-195.
14. Azab M el-S, el Zayat EA. Evaluation of purified antigens in haemagglutination test (IHA) for determination of crosses reactivities in diagnosis of fascioliasis and schistosomiasis. J Egypt Soc Parasitol. 1996;26(3):677-685.

15. Kaneko S, Feinstone SM, Miller RH. Rapid and sensitive method for the detection of serum hepatitis B virus DNA using the polymerase chain reaction technique. J Clin Microbiol. 1989;27(9):1930-1933.

16. Minuk GY, Sun DF, Greenberg R, et al. Occult hepatitis B virus in a North American adult hemodialysis patient population. Hepatology. 2004;40(5):1072-1077.

17. Yakaryilmaz F, Gurbuz OA, Guliter S, et al. Prevalence of occult hepatitis B and hepatitis $\mathrm{C}$ virus infections in Turkish hemodialysis patients. Ren Fail. 2006;28(8):729-735.

18. Fabrizi F, Messa PG, Lunghi G, et al. Occult hepatitis B virus infection in dialysis patients: A multicentre survey. Aliment Pharmacol Ther. 2005;21(11):1341-1347.

19. Besisik F, Karaca C, Akyuz F, et al. Occult HBV infection and YMDD variants in hemodialysis patients with chronic $\mathrm{HCV}$ infection. J Hepatol. 2003;38(4):506-510.

20. Kreutz C. Molecular, immunological, and clinical properties of mutated hepatitis B viruses. J Cell Mol Med. 2002;6(1):113-143.

21. Preisler AS, Schlayer HJ, Peters T, et al. Sequence analysis of hepatitis B virus DNA in immunologically negative infection. Arch Virol. 1993; 133(3-4):385-396.

22. Lili KS, Dagmar P, Christian M. Hepatitis B virus DNA in sera and liver tissue of HBsAg negative patients with chronic hepatitis C. J Hepatol. 2000;3:785-790

23. Gaeta GB, Rapicetta M, Sardaro C, et al. Prevalence of anti-HCV antibodies in patients with chronic liver disease and its relationship to HBV and HDV infections. Infection. 1990;18(5):277-279.

24. Feldman M, Scharashmidt BF, Sleisenger MH, et al. Gastrointestinal and Liver Disease. Pathophysiology, Diagnosis, and Management. Vol 2. 6th ed. Philadelphia, PA: WB Saunders; 1998.

25. Shire NJ, Rouster SD, Rajicic N, et al. Occult hepatitis B in HIV-infected patients. J Acquir Immune Defic Syndr. 2004;36:869-875.

26. Nalpas B, Pourcel C, Feldmann G, et al. Chronic alcohol intoxication decreases the serum level of hepatitis B surface antigen in transgenic mice. J Hepatol. 1992;15(1-2):118-124.

27. Oesterreicher C, Hammer J, Koch J, et al. HBV and HCV genome in peripheral blood mononuclear cells in patients undergoing chronic hemodialysis. Kidney Int. 1995;48(6):1967-1971.

28. Helmy A, Al-Sebayel MI. Isolated antibody to hepatitis B core antigen in patients with chronic hepatitis C virus infection. World J Gastroenterol. 2006;12(27):4406-4410.

29. Jilg W, Sieger E, Zachoval R, et al. Individuals with antibodies against hepatitis B core antigen as the only serological marker of hepatitis B infection, high prevalence of carriers of hepatitis B and C virus. J Hepatol. 1995;23(1):14-20.

30. El-Sadawy M, Ragab H, El-Toukhy H, et al. Hepatitis C virus infection at Sharkia Governorate, Egypt: Seroprevalence and associated risk factors. J Egypt Soc Parasitol. 2004;34 Suppl 1:367-384.

31. El-Gaafary M, Abou-Fetouh A, Zaki M, et al. Some epidemiological aspects of patients with end stage renal diseases. J Egypt Public Health Assoc. 2000;75(1-2):107-129.

32. Steinfelder S, Andersen JF, Cannons JL, et al. The major component in schistosome eggs responsible for conditioning dendritic cells for Th2 polarization is a T2 ribonuclease (omega-1). J Exp Med. 2009;206(8): 1681-1690.

33. Emam EA, Emam M, Shehata AE, Emara M. Impact of Schistosoma mansoni co-infection on serum profile of interferon-gamma, interleukin-4 and interleukin-10 in patients with chronic hepatitis $\mathrm{C}$ virus infection. Egypt J Immunol. 2006;13(2):33-40.

34. Fabrizi F, Dixit V, Bunnapradist S, et al. Meta-analysis: The dialysis mode and immunological response to hepatitis B vaccine in dialysis population. Aliment Pharmacol Ther. 2006;23(8): $1105-1112$. 
35. Shatat HZ, Kotkat AM, Farghaly AG. Immune response to hepatitis B vaccine in hemodialysis patients. J Egypt Public Health Assoc. 2000; 75(3-4):257-275.

36. Fabrizi F, Lunghi G, Finazzi S, et al. Decreased serum aminotransferase activity in patients with chronic renal failure: Impact on the detection of viral hepatitis. Am J Kid Dis. 2001;38(5):1009-1015.
37. Yasuda K, Okuda K, Endo N, et al. Hypoaminotransferasemia in patients undergoing long-term hemodialysis: Clinical and biochemical appraisal. Gastroenterology. 1995;109(4):1295-1300

\section{Publish your work in this journal}

Pathology and Laboratory Medicine International is a peer-reviewed, open access journal focusing on innovative basic research and translational research related to pathology or human disease. The journal includes original research, updates, case reports, reviews and commentaries on current controversies. The Academic Sponsor of this journal is the Chinese American Pathology Association (CAPA). The manuscript management system is completely online and includes a very quick and fair peer-review system. Visit http://www.dovepress.com/testimonials.php to read real quotes from published authors.

Submit your manuscript here: http://www.dovepress.com/pathology-and-laboratory-medicine-international-journal 